Cahiers $d u$ MONDE RUSSE

\section{Cahiers du monde russe}

Russie - Empire russe - Union soviétique et États indépendants

50/2-3 | 2009

L'Europe orientale, 1650-1730. Crises, conflits et renouveau

\title{
Sophia - Divine Wisdom, and justice in seventeenth-century Russia
}

La « Divine Sagesse » et la justice en Russie au XVII siècle

\section{Christoph Witzenrath}

\section{(2) OpenEdition}

1 Journals

\section{Electronic version}

URL: https://journals.openedition.org/monderusse/9743

DOI: $10.4000 /$ monderusse. 9743

ISSN: $1777-5388$

\section{Publisher}

Éditions de l'EHESS

\section{Printed version}

Date of publication: 15 September 2009

Number of pages: $409-429$

ISBN: 978-2-7132-2260-3

ISSN: $1252-6576$

\section{Electronic reference}

Christoph Witzenrath, "Sophia - Divine Wisdom, and justice in seventeenth-century Russia", Cahiers du monde russe [Online], 50/2-3 | 2009, Online since 13 October 2012, connection on 04 September 2022. URL: http://journals.openedition.org/monderusse/9743 ; DOl: https://doi.org/10.4000/ monderusse. 9743

This text was automatically generated on 4 September 2022.

All rights reserved 


\section{Sophia - Divine Wisdom, and justice in seventeenth-century Russia}

La « Divine Sagesse » et la justice en Russie au XVII siècle

Christoph Witzenrath

\section{AUTHOR'S NOTE}

This article was completed with the generous support of the Leverhulme Trust.

1 Representations of Sophia in icons, murals, consecrations and liturgies saw an impressive revival in Muscovy in the late sixteenth and seventeenth centuries. The present article traces reasons for their popularity in seventeenth-century Tobolsk and relates them to imperial culture, elucidating their significance on the Muscovite ${ }^{1}$ and Siberian background.

\section{Founding Sophia: the Tobolsk Archbishopric}

2 The pre-history of the consecration of the Sophia cathedral in Tobolsk, the conflicts and local devotion to it are telling for Wisdom's significance during this period: it became a means of pacifying the Siberian frontier. After the Time of Troubles, during which various armies devastated the land, a weakened Muscovite empire sought to strengthen its ties with the periphery. The costs for the Siberian cossack garrisons were out of control: as the tsar's decree explained, it had become impossible to discern in Moscow how much land was tilled in Siberia, for the land registers were incomplete. Huge quantities of grain had to be sent to Siberia, a heavy duty imposed on the peasants of the North, "therefore, [...] in the northern towns [west of the Urals] many peasants became impoverished and dispersed and [...] much deserted land was found." Patriarch Filaret, recently returned from captivity and his son Michael, elected tsar in 1613, installed a new archbishop supervising and reporting on voevodas - provincial gentry and nobles who 
served as governors and military leaders -, on local administration and cossacks to check up on the empire's finances. Initially, this device failed as there was sustained resistance. Cossacks beat clerics and the bishop's servants, chased them from the land the tsar had bestowed on the bishop and mocked the patriarch's public admonition. Due to economic restrictions, the tsar's armies could not intervene in local rebellions on the Siberian frontier. Sending an army required further food transports, without any guarantee that these would not be acquired illegally by soldiers to buy furs. Thus, the tsar would have financed competition to the fur trade and tribute, a rare source of readily convertible revenue needed, for example, for financing military reforms, which was one of the main reasons for conquering Siberia. The empire was ready to yield to local pretensions.

Despite local resistance, the first bishop of Tobolsk and Siberia, Kiprian (1621-1624), a cleric seasoned in diplomatic battles with Sweden over Novgorod, managed to establish himself in Tobolsk. Recognising his weak position, the strategies he employed involved building a solid economic basis for the archbishop's court, demanding that due respect was shown to law and compromising with local needs. ${ }^{3}$ Tobolsk voevoda Matvei M. Godunov defied the tsar's decree stipulating that Kiprian should dwell in the voevoda's court, being well aware of the insult implied to himself and his kin. Instead, Kiprian settled in a relatively humble secretary's court, paying a lump sum as compensation. Another sign of compromise was yielding to local pretensions regarding the patron saint of the new cathedral, for which the tsar had donated 1094 roubles. It was consecrated to "Sophia - Divine Wisdom" rather than "Resurrection of Our Saviour," as the tsar's ukaz and Kiprian had decreed - before leaving Moscow. Moreover, it deviated from Muscovite preference for the Dormition. ${ }^{4}$ The archbishop did not even ask the tsar in advance about this symbolical change. One of the reasons the voevoda reported was that, in view of the already nearly finished church of Sophia, another church was beyond the means of the 'poor' Tobolsk cossacks. Nevertheless, cossacks engaged in trade donated precious stones, adornments and land exclusively to Sophia; by contrast, donations by clerics and a Moscow based secretary varied, but were distinctly cheaper. ${ }^{5}$ One of the questions this article seeks to answer is why Tobolsk cossacks were particularly attracted to the cult of Sophia.

\section{Semen I. Shakhovskoi's Office of Sophia}

Among the sources related to Sophia up to the first half of the seventeenth century, the Sluzhba, authored by the prince and dvorianin Semen I. Shakhovskoi, is in many ways connected to Tobolsk, although it was written for and read in the Novgorod Sophia cathedral. ${ }^{6}$ One of these relations is Western in origin. Whereas earlier Muscovite explanations approached Divine Wisdom mainly in a christological way, Shakhovskoi also included the Marian version. ${ }^{7}$ The Mother of God is often related to Sophia in Russian Orthodoxy; Shakhovskoi, however, stresses the Latin idea of Immaculate Conception. ${ }^{8}$ This might be explained by his assignments : campaign service called him repeatedly to the western border and he was sent on a diplomatic mission to Warsaw in 1637. However, exposition to western Rus' ideas about Sophia was more direct, occurring in conditions less determined by conflict, though geographically out of the way, in Tobolsk. The first description of the Tobolsk icon (1625) notes it was a copy of the Polotsk version. The latter had disappeared during Ivan IV's occupation (1563-1579) of 
the Polish-Lithuanian town, when the tsar claimed to secure 'Sophia' the icon from the hands of the 'infidel' Protestants..$^{9}$ By the 1680's, the later Tobolsk icon copied the new Kievan style, influenced by the same Latin pictorial programs as Shakhovskoi. ${ }^{10}$ While the origins of the majority of Siberian cossacks related them to the former Novgorod lands, many "Lithuanians," mainly Ruthenian prisoners of war, had been sent to Siberia and some church books from Western Rus' print shops made their way to Tobolsk by 1625. ${ }^{11}$ Western influences as well as Muscovite and local traditions, possibly influenced by Novgorod inheritance of the many northern Russian settlers, were all palpable in Tobolsk.

5 Shakhovskoi repeatedly collaborated with Kiprian in literary production. He was banned to Tobolsk in 1622 , shortly after the consecration of the cathedral..$^{12}$ The prolific writer with extensive religious erudition served, as an officer, the successive tsars and various militias during the devastating internal strife, interregna and foreign interventions known as "the Time of Troubles" (1605-1613). He frequently suffered from conflicts with patriarch Filaret or, after the latter's demise, with his peers. He was sent as voevoda to Eniseisk in 1627-1632, stayed briefly in Tobolsk in 1632 and was banned to Tomsk in 1649. Each time, he was exposed to Siberian cossack customs serving as a voevoda. ${ }^{13}$ Parts of the Sluzhba correspond to these conflicts, such as about his uncanonical fourth marriage - earlier wives died during the dearth and campaigns of the Time of Troubles - or his cousins' inept game of tsars, a carnivalesque staging of a coronation in which he was involved through kinship, but apparently did not participate personally.

However, the Sluzhba can partly be read as representing cossack group authority exerting particular resources of power rooted in frontier conditions, which allowed the group to control the leader and the voevoda: ${ }^{14}$ "The arm of the elect keeps Divine Wisdom [...]"15 It brings to mind a motif of Muscovite and Byzantine wisdom literature according to which Wisdom aids rulers in the sense of mastering their own and their subjects' passions. ${ }^{16}$ Shakhovskoi interprets this passage through a reference to the Furnace Play, which became popular in the late sixteenth and early seventeenth centuries. The hirmos cited above starts: "The three youths in Babylon rebelled against the tyrant's orders, so they were thrown in the middle of a furnace, and feeling the coolness [protecting them], they cried, may the Lord of our fathers be praised!" ${ }^{17}$ In the play, three young servitors of Assyrian king Nebuchadnezzar stood up for their Jewish faith, disobeying the order to worship an idol. While they were powerless against the tyrant's will, God saved them miraculously, leaving the guards awe-struck - and Nebuchadnezzar later suffered God's punishment, viz. madness in the desert. The Furnace Play had an obvious affinity to the "rebellious seventeenth century." Public displays of fireworks and increasingly unruly skomorokhi involved in staging it led to tsar Aleksei's ukaz: the Furnace Play was forbidden during the Moscow rebellion of $1648-49 .{ }^{18}$ One of the factors that put an end to this powerful rising was the promulgation of the last Russian code of law, drawn up with the participation of the tsar's subjects. ${ }^{19}$ When quoting the Furnace Play, Shakhovskoi's intention, however, is hardly to incite rebellion - he had sufficient experience with cossacks, especially during his banishment to Tomsk in 1649, when it was Siberia's foremost rebel town, and also earlier as voevoda in Eniseisk..$^{20}$ As the present paper hopes to demonstrate, he looks for ways to reconcile the rebels' fervour and their particular interpretations of justice with the tsar's supreme court of appeal. 


\section{Postmodern Philosophy of Law and Muscovite Representations of Wisdom}

7 Muscovite literary sources tend to avoid political, legal or institutional terms, seeing symbols of the Divine in everything earthly. As elsewhere, Shakhovskoi is among those who interpret the legitimation of the tsar derived from Divine Wisdom as a cautionary representation:21 "[...] in her left hand a hidden and unknown mystery, impenetrable even for the angels." ${ }^{22}$ Although tsars are human and not angels, they share an intermediate aspect - power, knowledge, ultimate discretion - with the semi-divine ${ }^{23}$ angels. What restricts the angels must be applicable to tsars. If Wisdom's mystery is impenetrable for angels, surely it is for the human ruler, too. The experience of the ultimate "Other," transcendent Wisdom, in particular its aspect of justice, obstructs direct representation or total perception. Jacques Derrida, addressing the "possibility of justice" in deconstructivist terms, concludes that judges and rulers are impelled to decide in conditions of imperfect information, even as they try hardest. A juridical decision is structurally finite and judges cannot divest themselves of conditions of "urgency and precipitation, acting in the night of non-knowledge [...]," while justice as a process is infinite. ${ }^{24}$ Reacting in their own terms to such aporia, which leave no way out, medieval Russian literary sources refer to the parallel, the icon or copy of God represented by the tsar. The secret of Divine Wisdom helps the tsar to rule but it is not fully revealed neither to the angels nor, implicitly, to the tsar, a mortal similar to God regarding the tsar's power only. In practical terms, this meant that the tsar had to rely on advice, which every subject was obliged to give him - in political reality, of course, this was mostly the privilege of the boyars. They were well-connected through marital ties with the dynasty and among themselves, and the tsar's power rested on them, even though individually a boyar might succumb to the tsar's "anger" (gnev). His power in that respect was unlimited by any provisions, such as those in force in Poland, where nobles could only be judged by their peers. As primus inter pares in the boyar kinship network, with the help of Divine Wisdom the tsar adjudicated their conflicts among themselves so as to preserve this subtle network of power, marriage and heredity. ${ }^{25}$

8 It is more than coincidental that postmodernist legal theory helps to understand Shakhovskoi's Wisdom representation and some others. Derrida builds his theory on Levinas, who like many Jewish philosophers of his time treated the religious tradition of the Bible and Torah as a theoretical source of the first order. ${ }^{26}$ There is an emerging scholarly consensus concerning the old Testament, which was transmitted to late Muscovy in the Scriptures and Byzantine writings, that wisdom became related to law. Ancient Jewish wisdom, an ideology of the literate privileged few, assumed a direct relation between one's deeds and how one fares in life. During the crisis of wisdom literature in the book of Job, emphasising inherent contradictions in this notion, however, it was transformed to include both obligatory adherence to the law ${ }^{27}$ and inconceivable Wisdom of God, realigning the previously little connected $\mathrm{JHVH}^{28}$-cult and wisdom. During foreign rule and captivity, certain types of regimes became acknowledged as God's reign on earth, although others were perceived quite differently. Therefore, late Jewish wisdom literature accepted interference by the new empires, while admonishing both ruler and subjects to observe the laws and due process of law, thereby attaining eternal life. ${ }^{29}$ Aporia of justice and the ordeal of the individual, meek believer, which in Job coincides with theodicy - notwithstanding its resolution in the Jewish, 
Christian and Muslim religious traditions by hints to life in the beyond - gave rise to Levinas' and, following him, other postmodernists' challenge to legal theory. Even before Levinas turns systematically to philosophy, he takes from this tradition the normative models according to which communication between humans ought to be determined in concepts like goodness and empathy. For Levinas, the ultimate Other, embodied in another human being, whom we encounter in his or her individual face, is the test to which any justice is to be put. The other human being always faces me as a person in need of protection and concern to such a degree that I am overburdened in all my finite possibilities to act and thus concurrently become aware of a dimension of infinity..$^{30}$

9 Assuming thus an extra-legal second source of justice, postmodernist and other recent contributions add a new perspective to legal positivism, which, at least since the enlightenment, posits that the measure of justice is equality. In Kant's categorical imperative, every moral subject thinks in its own mind, secluded, about the principle according to which everybody can live and lives accordingly, presupposing a position of the subject outside of discourse. It excludes that which is beyond the limited reason of any moral subject, i.e. the 'Other'. Thus, for Levinas Kant's aim has to be achieved in dialogue, encountering the real 'Other' who faces me in his or her absolute singularity, places a unique demand upon me and seeks my response. ${ }^{31}$

10 At the same time, Levinas reverts to some of the earliest sources of legal theory in old Hebrew Wisdom literature, which were transmitted to Muscovy. Here we approach a key aspect of the aporia of justice. To act justly Muscovites had to treat other subjects of the tsar both as equal, i.e. entitled to the symmetrical treatment of norms, and as a totally unique person who commands the response of ethical asymmetry ${ }^{32}$ - although in many regards these became subsumed to categories of group, kin, religion and forms of tribute, service or subsistence. ${ }^{33}$

11 It makes sense that Shakhovskoi evoked a representation of alterity, for he expounded in his petition his hardship, grounded in the exceptional conditions of the Time of Troubles, and the loss of three wives, without condemning canonical law which forbids marriages in excess of three, or the patriarch who acted as judge and forcibly divorced his fourth. ${ }^{34} \mathrm{He}$ demanded to be judged on the backdrop of these experiences rather than by the letter of the law alone. The Sluzhba itself is a representation of alterity, for it constantly shifts between interpreting Wisdom along the eucharistic themes, on the one hand, of Mary, and, on the other hand, of Christology, leaving an androgynous impression of constantly mirrored identity. As we will presently see, in Siberia Shakhovskoi entered an environment in which people had similar concerns, although for different reasons.

\section{Wisdom, Ivan IV and Sophia Alekseevna}

Concerning another expression of alterity, the already mentioned secret of Wisdom, Shakhovskoi was on common grounds with more official interpretations, such as the 'Stikh sviatyia Sofiia premudrosti Bozhiia' included in the sixteenth-century Novgorod chronicle. ${ }^{35}$ The commonly accepted way to deal with the dilemma of imperceptible Divine Wisdom and justice was worldly wisdom, or the duty to give wise advice. ${ }^{36}$ However, during the terror which Ivan IV unleashed facing the opposition of the metropolitan - and post-mortem criticized by Shakhovskoi ${ }^{37}$ - the tsar insisted that Wisdom's secret was fully revealed to him, as his inner truth. He redoubled and 
neutralised the aporia of justice and the paradox of his apparent erring sinfulness by selffashioning as holy fool, who by his sins denigrated and humiliated himself "like" Christ, therefore gaining Wisdom and power. Humble as he posed in his own mythmaking, although hardly as defiled as the actual holy fool, he saw himself humiliating his vainly proud opponents. A paradigm normally contradicting the tsar's virtues, foolishness in Christ allowed to ingratiate himself to his subjects using carnival humiliations and punishments. In turn, in the image of the chaste, wise and just tsar he punished his foes with righteous terror. ${ }^{38} \mathrm{He}$ used this myth of a reciprocal relationship with his people as an alibi for rejecting the boyars' advice: humble as he was he became both donor and recipient of advice, ${ }^{39}$ conflating alterity.

This helped to overplay a personal weakness: since his parents had died early in Ivan's childhood, he lacked the role-models for navigation within the carefully-woven network of boyar kin, both enhancing the tsar's power and informally limiting his authority. ${ }^{40}$ Besides, this childhood experience of exclusion opened the door to perceptions of holy foolishness. Staying thus outside of the juridico-political battles of his day, he added to his own sense of vulnerability and the perceived betrayal of his own people which led him to apply for asylum to Elizabeth of England. Left to itself, without deliberation - or advice - the idea of justice is always dangerously close to the worst: "for it can always be reappropriated by the most perverse calculation. [...] And so incalculable justice [which exceeds the calculable law, being the unpresentable that exceeds the determinable] requires us to calculate." ${ }^{41}$ Ignoring the Orthodox obligation to accept advice and the constraints of boyar kinship, Ivan employed his fully transcendent interpretation of Wisdom and justice to legitimate purifying and cleansing the realm, among others, the Oprichnina terror. Since kinship and patronage was a universal social structure in Muscovy, the terror extended to the greater population. ${ }^{42}$

\section{Representations and Social Practices}

Compared to Ivan "the Terrible," Shakhovskoi's Sluzhba is a particular representation of Muscovite imperial culture, drawing on commonly accepted sources that permitted variant interpretations. It would be misconceived as a dissident view. Defining the import of representations on everyday life, Roger Chartier highlights that "breaking with the old idea that endowed texts and works with an intrinsic, absolute and unique meaning which it was the critic's task to identify, history is turning to practices that give meaning to the world in plural and even contradictory ways." ${ }^{43}$ Thus, the question arises whether within imperial culture practices existed that gave meaning to and communicated plural if not contradictory points of view which are, however, fully commensurate with the tsar's pretension to be the institutionally unbridled court of ultimate resort.

Shakhovskoi addresses tensions between law, justice and power. In the Slavic Bible, first printed in Ostrih in sixteenth-century Poland-Lithuania, Wisdom speaks: "Mnoiu tsarie tsarstvuiut, i silnii pishut pravdu." ${ }^{44}$ By contrast, Shakhovskoi changes perspective and speaks of Wisdom in the third person, highlighting meanwhile the role of bureaucrats: "Toiu tsarie tsarstvuiut [...] i mudrii pishut pravdu." ${ }^{45}$ The Sluzhba traces the role of law in an Orthodox economy. The Word (Logos), or Sophia - Divine Wisdom is incomprehensible to humans and angels. Present at the creation of the world, it contains all knowledge, in other words, identity and alterity. Incarnated as Christ in the temple of 
the body of the immaculate mother of God, identified with Sophia and fed by her breasts, she gives not only eternal life to humans, but also length of life in this world. She adds peace and executes all good measures for those who follow her paths, that is, engage in just ways of life, to which she adds a court and code of law, which is, in other words, worldly wisdom. The line mentioned above continues:

The hand of the elect keeps Divine Wisdom of God [...] she sits by the strong town gate and tells those who dare to address her [:] share my joy, you who search for me [...] she secures the path of life for us. Those who keep to justice inherit Divine Wisdom, called Sophia, since the blessings of her nipples taste better than wine ${ }^{46}$ and the fragrance of her peace is better than all aromas, let us move [that is, follow her onto the right path $]^{47}$ and she will give us laws and a court of justice. ${ }^{48}$

In this text, there is tension between the tsar's justice and the justice of Divine Wisdom respecting the law, notwithstanding the perception that Wisdom aids his reign. The underlying image of a path - on which the collective "we" walk, those who dare follow Wisdom - represents worldly wisdom and justice as a process rather than as any fixed entity revealed exclusively to the elect. ${ }^{49}$ However, since earthly wisdom cannot fully perceive transcendent, absolute Wisdom and justice, Shakhovskoi did not deny that the tsar was the court of ultimate resort. Orthodox economy cannot accept the views of Kierkegaard and Derrida - that aporia of justice implies that the moment of the just, adequate decision takes place in the night of ignorance, of "madness" - that any call for justice requires the experience of impasse, otherwise it will be unable to follow its moving aim. As mentioned before, justice is an interminable process and discourse in which complete information cannot be obtained by definition. However, at the same time it is irreducibly urgent, therefore it cannot wait..$^{50}$

17 In eulogies for the regent Sophia Alekseevna (1682-1689), she is said to "capture the Wisdom of God and impart it to her people." As far as justice was concerned, capturing Wisdom meant the pursuit and study of law and book-knowledge. ${ }^{51}$ Acknowledging that law is a discourse in need of a degree of permanence and reliability, these legitimating representations underscore due process of law. However, justice is more than the unfolding of a calculable process codified in the laws..$^{52}$ Therefore, and since Sophia was up against increasing pressure by the court faction of her father's heir, Peter, her supporters interpreted the traditional myth of the blessed womb of the tsaritsa. They construed a way in which Divine Wisdom, the Logos of the virgin Sophia's "lover," Christ, could, though not be incarnated, in-dwell in her to radiate outwards over empire and subjects in her activity. The fire of the Logos melted ashes to become glass, from which the temple of Wisdom, the translucent womb, was formed. An innovative extension of Orthodox eschatology, especially concerning female rulers, ${ }^{53}$ this representation of the "mystical ground of authority" was adequate for an absolute monarchy. This 'mystical ground' is Derrida's answer to the aporia of justice, the night of ignorance. The myth of the blessed womb instantly transcends this darkness symbolically. Instead of pointing to violence in human interaction as an irretrievable act founding the social order, which Derrida emphasises, this image points to the violent, but also graceful act of coming into being. As Isolde Thyrêt shows, relying on and developing the traditional role of the tsaritsa and tsarevny was best suited for the fragile network of boyar families who accepted the ruler as arbiter for their prevailing concern, internal stabilisation..$^{54}$ While eulogies stressed at the same time the process of the law and the tsar's access to Wisdom, seventeenth-century court cases predominantly ended 
by an act of mercy, usually protecting social status and underlining the limitations of justice. ${ }^{55}$

\section{Representations of Wisdom in Siberia}

Drawing a sharp dividing line between deconstructivism and Jewish, Christian and Muslim eschatology, which resolve aporia of justice by hints to redemption in the beyond, Derrida points out that the "mystical ground of authority" signifies a wall of silence and violence. He explains this "wall" by the founding acts inscribed in the sources of any legal tradition, whenever a new order comes into being or is changed. In his view, it is neither just nor unjust, since it can neither rely on nor be judged by reference to pre-existing foundations; it is violence consequently inherent in all laws. ${ }^{56}$ Whether or not we agree with such relativism, Derrida's image of the wall can further understanding of the ruler's need for both: for representations of access to Wisdom and the acknowledgement that Wisdom is ultimately inaccessible. In the rapidly expanding Muscovite empire, distance and the amount of information increased, while the available formal means for reducing complexity included documentation, standardisation of procedure and autonomous internal rule-making. Outside the most important spheres of government - security, public safety, collecting taxes and mobilisation of resources early modern Russian bureaucracy could not do without the informal resources of power and subsistence provided by gift-giving, bribes and patron-client relations. Although some of the forms of exchanges practised informally involved administrators with local groups, lack of institutionalised public control distinguishes historical bureaucracy from the modern era. ${ }^{57}$ Muscovites often experienced interminable law suits which were often preserved without resolution or ended with an act of mercy..$^{58}$ Muscovites coined a term for these more practical aspects of the aporia of justice, using a metaphor of spatial movement obtained from their experience: volokita, derived from the root volochit', to drag; to cite an example that was certainly on Siberians' minds, volok "portage" is derived from the same root - arduous, limiting free movement on the waterways, but still passable in a different mode of movement..$^{59}$ To deal symbolically with the most divisive political consequences of difficulty to get to justice, Orthodox concepts of legitimacy ascribed to the tsar prominent, if not exhaustive, access to Divine Wisdom and justice..$^{60}$

19 Given the limits of state authority in the early modern era and the specific nature of power resources available to the tsar in Siberia, such access could not bar other representations. Shakhovskoi may well have written the above adaptation of Prov. 8:1-21 with his Siberian cossacks in mind. Considering the resources of power available to cossack groups, many of which were engaged in trade, this was a fitting expression of their needs. In 1650, the second delegation of Tomsk rebels wrote a letter from the prison cell in the Moscow Kremlin into which they had been cast for daring to present their collective petition. They wrote secretly to their comrades in Tomsk, with whom they shared the experience of deposing and arresting the voevoda. Conditions had changed in the capital since the pacification of the parallel Moscow rebellion (1648-1649). In the letter, tension between different perceptions of justice is palpable. However, there is also acceptance of the tsar's role as legitimate ultimate arbiter. Their way out of this dilemma, at a point when everything was still open in the lawsuit, was to extol their brethren to maintain unity even under investigation, as they had promised: 
You, brothers, our masters, shall stand all together as one man, so that you will not be tried.

And do not hand us in, brothers atamans molodtsy! We stand in for the law ${ }^{61}$

for the entire town; even if the sovereign orders to hang us all, we will die maintaining the law and waiting for the sovereign's mercy. Therefore we bow to you many times, our masters: live in Christ!62 which they had explained in the petition; nevertheless, they professed that they would keep to it. Again, this endurance and the procedural view of justice implied by waiting for the tsar's mercy and their conviction to maintain the law are conflicting with the divinely ordained power of the tsar, but not with views espoused by Shakhovskoi. Since the tsar depended, at least partly, on the fur tribute, they speculated that the outcome might be favourable; indeed, the punishment meted out after their release and return to Tomsk was comparably moderate despite the tsar's well-known convictions: five years after the start of the insurrection in Tomsk, 65 people in all - including family members of the banned - were sent to Iakutsk, retaining ranks. ${ }^{63}$

thension between their oaths to serve loyally, generally accepted notions of treasonas in the institutional mechanism of the lese-majesty offence on which they relied in their petition - and their own point of view meant that cossacks had to find firm ground. They formulated among themselves a guiding idea interpreting the lese-majesty according to their needs, fully anchored in service requirements. This guiding idea became obligatory by signing the petition, in a given place and social group, and temporarily - for an event and during the following investigation, for example. The cossack group thus formed and reinvigorated showed an inclination, mentioned above, to detach itself from society. Petitions and the specific forms of cossack group organisation mutually reinforced their position. Petitions were discussed, formulated and signed publicly as part of limited, but vigorous control exerted in the Siberian partial - that is, ostensibly limited to one issue, namely service - public sphere, which helps to explain why the administration performed rather well in Siberia. ${ }^{64}$

The degree to which the public can control administration depends on resources of power and on institutionalisation. The ideal forms of modern deliberation, mentioned above, were quite far from Siberian realities. The physical spaces in which they met were largely ephemeral: in the church refectory, the market place, in front of the governor's office, during reviews, campaigns or on the river bank. ${ }^{65}$ Nevertheless, the cossack tendency to acclaim legitimate voevodas as tsars, effectively making them impostors, whereby they intended to make them dependent on local communities, convinced Kiprian that he was to support institutionalisation of cossack customs, as he did in the Sinodik Ermakovym kazakam. Cossack customs of electing, advising and deposing their leader were described in the terms of the Tales of advice and the images of unanimous rule similar to the tsar and his wise boyars. ${ }^{66}$ Cossacks appropriated these parts of wisdom discourse to articulate the custom of deposing a voevoda not consenting to the group's aim, for he "rejected" their advice. ${ }^{67}$ In 1648 partisans of the first voevoda of Tomsk, Shcherbatyi, who had been deposed by rebels, tried to justify one of the voevoda's measures which had alienated the cossacks by citing the rebels' decision. The clash was about the mode of building the new fortifications, and Shcherbatyi's cossack partisans tried to demonstrate that the rebel cossacks had earlier agreed huge payments to that end, somewhat out of step with the tradition of work dues they owed: "according to the advice of all servitors [...] [and] on their [...] orders." ${ }^{\prime 8}$ In wisdom literature, cossacks

Cahiers du monde russe, 50/2-3|2009 
sought models for explaining events, which they needed to sustain their position against the allegations of treason by their local foes. Kiprian, after returning to Novgorod as a metropolitan supported this process of appropriation and reformulation for local purposes by bequeathing an Ostrih Bible, Iosif's "Enlightener," the writings of Dionisii Areopagit and Maksim Grek, the Stoglav and the Sudebnik to Tobolsk, containing ample material on top of the menologies available before. ${ }^{69}$

Shakhovskoi shared with these writers emphasis on limitations to the ruler's power and adherence to written law, approvingly mentioning one of his sources, the rather uncommon fourteenth-century collection of juridical treatises, "Just Scales" (Merilo pravednoe), a mirror of princes with a second part dedicated to judges. Although only preserved in five copies of the fifteenth-sixteenth centuries, it found its way to the Wisdom-murals of the Golden Hall in the Kremlin (between 1547 and 1553), a central place for Muscovite political representation, in which boyars and other courtiers spent much of their days. Raising his gaze, the tsar recognised on the lower vault opposite the throne a candle-stick in the hand of a human. Its spark of light led this Other through a mixed medieval and early modern field of tensions - below, the apocalyptic sevenheaded devil or dragon, on opposed wings of painted doors the vices and virtues - onto the "narrow path" towards justice and Wisdom on top of the vault reminding the tsar of the Orthodox conditionality of authority. However, as Michael Flier rightly emphasises, visitors and litigants encountered the Last Judgement theme in these murals culminating above the throne, ${ }^{70}$ a representation of the "mystical ground of authority." 71 The luminaire is related to the law in the Merilo's foreword. Ivan-Volk Kuritsyn, a "Judaizer" put to death for heresy in early sixteenth-century Moscow, inserted the Merilo into his Rudder, to provide for "just court of law." 72 The throne room, therefore, contained both representations of the tsar's likeness to the Word and of the tension resulting from aporia, the darkness surrounding the tiny light of earthly wisdom, and its resolution by virtuous adherence to the norms of procedural law and the promise of ultimate salvation.

Passed on in the literature sent to Tobolsk on behalf of Kiprian and quite possibly observed during audience during their journeys accompanying the fur tribute or documents, ${ }^{73}$ this appealed to Siberian cossacks. The allegorical scales of justice attributed to Divine Wisdom in the Merilo were depicted in the Golden Hall vault among the other virtues and in the Siberian coat of arms' wisdom imagery ${ }^{74}$ Representations of Wisdom were also used among cossacks and peasants. In one such case, two months before the 1648-1649 rebellion, Tomsk peasants managed to send a petition to Tobolsk, bypassing the voevoda of Tomsk who wished to suppress it. One of them, Maksim Zorkal 'tsev during supper in the presence of two mutually opposed officers (deti boiarskie) employed a representation of Sophia, describing the way to Tobolsk: "I will go to Narym, and [...] up to Surgut I know the whole Ostiak language, and beyond we will go to the Mother of the Sun." ${ }^{75}$ If, as Pokrovskii states without foundation in the text, the peasants proposed to flee into the vast spaces of the taiga, they would have abandoned their plots close by an important transport and trade centre. In their petition, they argued for habitual use of their fields against the pretensions of the voevoda. Proposing a different interpretation of the quote above, it is obvious that these peasants sought the iasak people to trade furs. However, just as the cossacks they sought justification for travelling. Citing their aim as the "Mother of the Sun" they referred to Wisdom's cathedral, i. e. earthly wisdom, reminding that the fire of the Word, its energy, would not only incarnate Christ in the Last Days, but also, in the meantime, give a court of justice 
to those who followed Wisdom. Zorkal'tsev amalgamated justice and particular, private aims in one sentence.

Moreover, in popular Russian songs, in icons and literature, the themes of the sun as Godfather, earthly wisdom and the Mother of God as mediator are often linked. ${ }^{76}$ On maps by Semen Remezov, from within the walls and twelve towers, the image of the Second Jerusalem, its new temple, in other words the Tobolsk cathedral of Sophia sends sun rays across the Siberian lands and towns or is situated in the centre of concentric circles. Focusing on cartographies, Valerie Kivelson rightly relates these images to the widely observed practice of due process and equal justice in Muscovite Siberian courts. This practice even imparted a modicum of redress to peasants and natives, needed for their local knowledge and as skilled sharpshooters for intact sable furs shot through the eye. Still, encounters between cossacks, officials and "treacherous and mutinous" natives were often violent, especially during first contact and re-negotiation of the terms of trade. $^{77}$ In local Siberian conflicts, central interference was one potential source of power among others actively sought by participants and they represented this practice by the imagery of sun rays, invoking the process of law.

Listing the stations on the way to Tobolsk, Zorkal'tsev evoked another representation of the process of law. Equal justice and due process could only be found in spatial terms, for Muscovites replaced abstract entitlements, individual rights and freedoms developed at the same time in England and its empire, by "a legal language of rights fully grounded in place." As Kivelson has shown, while the rights of nomadic subjects were protected to some degree, they were imagined in terms of sedentary life. The significance of assigned place became obvious by the impossibility of the opposite: at least in theory, free movement of people was prohibited both by law and custom. ${ }^{78}$ Given the costs of travelling, social dislocation and the losses caused to the tsar's income by illicit fur bartering already mentioned, there were many reasons in an expanding empire for these provisions. Travellers needed the governor's permission, which was rigorously checked by his patrons or clients ruling in other towns. Whoever wanted to appeal to a higher level court without wielding other local and imperial resources of power, for example rebels governing a town or the seal of the customs official, was well-advised to enlist the support of the locals; in this case, the natives. ${ }^{79}$ Moreover, the bishops added to the spatial perception of justice. Relying on Kiprian's prerogative to supervise the voevoda, his successors sent local petitions to the court of appeal in Eniseisk, Tomsk or Tobolsk, bypassing the voevoda.

Spatial perceptions of justice fitted to cossack concern with overland trade. Late in the seventeenth century, the Tobolsk cossack, cartographer, architect, Siberian patriot and icon painter Semen Remezov, mentioned above, wrote a short treatise On Peaceful Order:

On peace [we] learn from the example of word of mouth spoken in sensible conversation: [...] it is becoming to the wise man to know various customs and codes of law enabling to rule cities and forts sagaciously [...] for our fatherland needs judicious council and wisdom [...] to placate the internecine struggles in our towns curing them by good examples. ${ }^{80}$

Emphasis on deliberation and plural sources of law and custom makes this a representation of the seventeenth-century Siberian state of mind openly admitting alterity that Kivelson finds on the maps. In this regard diametrically differing from European colonial maps, they depict the natives and do not even eschew depictions of cruelty committed by the conquerors, inscribed into the landscape. ${ }^{81}$ 

dress appear. The next paragraph stresses that "real wisdom" means self-restraint in analogy to a ship prudently staying in harbour during a storm. Despite the caution, the association of justice and peace with travelling and trade is obvious. Contrary to prevailing perceptions, Siberian cossacks were among the privileged few in the empire who received their salary - despite or rather because of frequent rebellions - regularly and fully, unlike other early modern mercenaries even in Europe. This endowed cossacks not only with the means for serving in distant places, but also to engage in overland trade, a practice the chancellery could not stop as long as they performed their service duties or found replacement hirelings. In these conditions of a thriving and expanding economy, local conflict was intense, and since frontier conditions meant that it evolved between cossack groups, tension was palpable. Even so, due process and procedural law helped trade flourishing and cossacks emphasised it.

The reforms of Tobolsk voevoda (1623-1625) Iurii Ensheevich Suleshev, relieving Godunov, meant a new level of due process in the relations of the state, the voevoda and the cossacks. Where there had been de facto possession of land on the part of the cossacks, they lost some unauthorised privileges but won legal guarantees. These reforms came under attack by the already mentioned cossacks who had ridiculed the patriarch's admonition: they tried to acclaim the voevoda as tsar to incline him to the local by the implicit threat to denounce his "connivance." The bishop's newfound strong position and his and the voevoda's reliance on procedural norms saved the voevoda and the reforms. ${ }^{82}$

\section{Conclusion}

In spite of their image of oppressed unruliness, Siberian cossacks appropriated Wisdom of God imagery and literature, emphasising due process of law and institutionalisation of cossack customs. After the 1620 s reforms, the cult of Sophia - and bishops as intermediaries - became popular among the cossacks as they increasingly participated in trade and mobility, resulting in mounting local conflict and interregional contacts. Muscovy's historical bureaucracy ${ }^{83}$, the dynasty, courtiers, cossacks engaging in trade and other groups aimed to resolve the increasingly visible tension between law, court decisions and justice by administrative law, independent rule-making for internal use and the myth of the ruler. In an expanding empire, pursuing justice meant overcoming arduous travel distances and mounting institutional obstacles. Face-to-face relations traditionally limiting abuse of power increasingly incurred impediments; public control of the administration was imperfect. Such aporia of justice - insurmountable obstacles in the course of justice due to lack of information, limited resources or inadequacy of technology to overcome distances quickly enough to meet urgent demands - were mitigated chiefly by eschatology, referring its victims to redress in the beyond. This was important in an empire in many places built on serfdom, where serfs were increasingly reduced to the seigniorial court. ${ }^{84}$ The code of laws of 1649 found few contemporary parallels abroad in terms of dialogic, inclusive and formal law which form part of the central factors determining effectiveness of prosecution and the consciousness of law. However, for much of the population, this achievement slowly faded as since the last decades of the seventeenth century they found themselves progressively excluded from most courts of law.

Cahiers du monde russe, $50 / 2-3 \mid 2009$ 
32 At the other end of the spectrum, Siberian cossacks in many cases had the necessary clout to successfully press their demands. They expressed their experiences in images of alterity and due process of law. These represented attempts to surmount internecine local conflicts causing participants both to seek outside imperial interference and, in turn, use local resources of power to influence central rulings. Public spheres are a minimal precondition for overcoming aporia of justice; under Muscovite conditions they were ostensibly limited to service issues - although in practice they could have far more extensive significance, as trade disputes concealed as service exchanges show. However, the ephemeral nature of limited public spheres in early modern Siberia meant instability, as the many local risings demonstrate.

As Muscovy recovered from the Time of Troubles, imperial culture accommodated divergent representations of Divine Wisdom in the various local, legal and customary rule settings, drawing on acknowledged discourse in the Orthodox Church. Imperial legal culture, limited as it was materially and in institutionalisation, recognised the alterity of legal subjects commanding sufficient means of power: the voevoda asserting extra treatment due to losses caused by service assignments or strokes of fate, the cossack similarly demanding special consideration and, perhaps above all, the Siberian cossack group claiming to be unable to serve if their demands were not met. These had to be considered on a case base, in which local power, merit, local and imperial custom and rules, kin and patronage were decisive factors. At least in Siberia, focal points for the process of justice existed in the courts of appeal, while reserving for the tsar the institutionally unbridled court of ultimate resort: local actors strove to reach him as well as the archbishop or the voevoda of Tobolsk, circumventing local officials. A boyar in office in Tobolsk favoured clients throughout Siberia; however, his power was limited by the usually brief - two to four years - tenure and especially if he was actually banned.

Reviving medieval, Byzantine and Biblical traditions, Wisdom imagery and literature promoted the rule of law, knowledge of divergent legal and customary traditions, deliberation as a precondition of decision, and mercy, which was acknowledged by rulers such as Sophia Alekseevna. ${ }^{85}$ Elevated expressions were used by elites - both central and local - to render imperial culture more flexible. At least in Siberia, parts of such views like the "right" to give advice and deliberate - appropriated by cossacks often effectively limited the power of voevodas.

Nevertheless, the interpretation of Wisdom put forward by Ivan IV remained viable as it had been to differing degrees all over Europe until the late medieval period, and especially in frontier regions. It could justify violent retribution against so-called traitors, putting a pragmatic if crude end to incessant squabbles. In reaction, local groups took care to promote a carefully groomed image to the outside world, downplaying internal divergences, while the siberian chancellery collected and compared any information obtainable to overcome the lack of power at the local level. 


\section{NOTES}

1. Present day use as a historical period encompasses Siberia.

2. N.N. Pokrovskii, ed., Tobol'skii arkhiereiskii dom $v$ xVII veke [Tobolsk archbishopric in XVII century], Novosibirsk, 1993 (Istoriia Sibiri. Pervoistochniki, vyp. IV [History of Siberia, primary sources, vol. IV]), kn. “B”, 1. 124vº-125, p. 173.

3. On due process: G.G. Weickhardt, "Due-Process and Equal Justice in the Muscovite Codes”, Russian Review, 51, 4 (1992): 463-480.

4. After five centuries, in the reign of Ivan IV, Vologda was the first diocese to choose Sophia as patron saint of the cathedral. This precedent and the Novgorod cathedral surely influenced Tobolsk, which formerly belonged to Vologda diocese; however, it does not fully explain the 1620 consecration. Cf. M.B. Pliukhanova, "O tradiciiakh Sofiiskikh i Uspenskikh cerkvei v Russkikh zemliakh do xvI veka" ["Churches consecrated to saint Sophia and to the Dormition in Russian lands before the $\mathrm{XVI}^{\text {th }}$ century"], Lotmanovskii Sbornik [Lotman collection], 2 (1997): 484-510.

5. Christoph Witzenrath, "Remote Power in the Orthodox Church. The Muscovite Empire, Cossacks and the Foundation of the Episcopal Residence of Tobolsk and Siberia," (in German), in Christian Hochmuth and Susanne Rau, eds., Machträume der frühneuzeitlichen Stadt (Constance: UVK Verlagsgesellschaft, 2006), 309-332, Engl. abstract: 387-388. Cf. also Elena Konstantinovna Romodanovskaia. "Kiprian Starorusenkov," SKKDR, III/2, 156-163.

6. On attribution: Fedor [or Théodore] G. Spasskii, "Sluzhba Sofii Premudrosti Bozhiei kniazia Simeona Ivanovicha Shakhovskogo" ["The office of Sophia Divine Wisdom by Simeon Ivanovich Shakhovskoi"], in F.G. Spasskii, Russkoe liturgicheskoe tvorchestvo po sovremennym mineiam [Creative liturgy in Russia in contemporary menologies] (P.: YMCA Press, 1951), 266.

7. Ibid., 267-268. A. Nikol'skii, ed., Sofiia Premudrost' Bozhiia [Sophia, God's Wisdom], (SPb., 1905), annexe III.

8. John Meyendorff, “Wisdom-Sophia," Dumbarton Oaks Papers, 41 (1987): 401.

9. E.L. Keenan, The Kurbskyi-Groznyi Apocrypha, (Cambridge, MA, 1971), 33-35. Pokrovskii, Tobol'skii arkhiereiskii dom, kn. "A", 1.14, p. 42; kn. “Б”, f. 39, p. 91. Sergei Bogatyrev, "Battle for Divine Wisdom," in Eric Lohr, Marshall Poe, eds., The Military and Society in Russia 1450-1917 (Leiden: Brill, 2002), 355-356. I am grateful to S. Bogatyrev for pointing out that the late sixteenth century Vologda registers contain references to displaced Polotskans.

10. Donald Fiene, "What is the appearance of the Divine Sophia?," Slavic Review, 48, 3 (1989): 471; Evgenii [Bolkhovitinov], Opisanie Kievosofiiskogo sobora i kievskoi ierarkhii [Description of Kiev Saint Sophia cathedral and Kiev ecclesiastical hierarchy] (Kiev, 1825), 24. On a third Tobolsk version: V.N. Alekseev, E.I. Dergacheva-Skop, "Novonaidennoe svidetel 'stvo ob ikonah 'Sviataia Sofiia premudrosti bozhiia' i 'Raspiatie,' predpolozhitel'no prinadlezhashchikh kisti S.U.Remezova" ["New data on icons 'Saint-Sophia, God's Wisdom' and 'Crucifixion,' attributed to S.U. Remezov"], in E.K. Romodanovskaia, ed., Problemy istorii russkoi knizhnosti, kul'tury i obshchestvennogo soznaniia [Historical Problems of literature, culture and collective consciousness in Russia] (Novosibirsk: Sibirskii khronograf, 2000), 264-274. 
11. N.F.Emel'ianov, "Tomskie sluzhilye liudi 'litva' v xVII-pervoi chetverti xVIII v." ["'Lithuanians' service men in Tomsk in XVII ${ }^{\text {th }}$ and first quarter of XVIII ${ }^{\text {th }}$ century"], in Aleksei P. Okladnikov, et al., eds., Problemy istoricheskoi demografii SSSR [Problems of historical demography in the USSR] (Tomsk: Izd-vo Tomskogo universiteta, 1982), vol. 2.; N.N. Ogloblin, "Zagovor Tomskoi 'litvy' v 1634 g." ["The conspiration of the Tomsk 'Lithuanians' in 1634"], Chteniia $v$ istoricheskom obshchestve Nestora letopisca [Readings in the historical society of Nestor the annalist], 8 (1894), 116-127; Pokrovskij, Tobol'skij arhiereiskii dom, 239-240.

12. S.F. Platonov, Drevnerusskiia skazaniia i povesti o smutnom vremeni XVII veka [Ancient Russian Narratives and Stories about the XVII ${ }^{\text {th }}$ century Time of Troubles], Sochineniia [Works], vol. II (SPb., 1913 [1888] or Russian Reprint Series, XXVIII/2, The Hague: Europe printing, 1966), 297.

13. Ibid., 451-452; Keenan, The Kurbskyi-Groznyi Apocrypha, 34-35, 183, 186. See also SKKDR, III/4, p. 275-286.

14. C. Witzenrath, Cossacks and the Russian Empire, 1598-1725. Manipulation, Rebellion and Expansion into Siberia (London: Routledge, 2007), 33-34: formed by unrelated members, cossack primary groups searched for group-immanent ways to reduce their members' anxieties under threatening conditions, relying on face-to-face relations. Unlike other primary groups, the cossack group was not based on kinship. There was an inclusive phase up to the oath delivered to each other in the cossack circle. Prospective members could not be forced to take the oath or agree to rules. The group was formed to provide mutual protection, enable economic pursuits in the steppe and for raids and campaigns, since cossacks acted in an environment in which the influence of the state and society beyond the few fortresses was limited. Union was determined by common aims, not by considerations of social status. Within the group, all members were valued according to their abilities and usefulness for realizing common goals. An exclusive period followed the taking of the oath which obliged all members to observe the rules and adhere to the agreed aim. Union was temporary; the early - and many later - cossack groups dissolved after one season. Leaders were elected only after the cossacks had agreed on a common aim. Their authority derived - at first exclusively - from their perceived ability to fulfil the common group aim. The group, which could depose a leader if he did not pursue group aims, tightly controlled him.

15. "Ruka izbrannykh uderzhit premudrost' Bozhiiu...," A. Nikol'skii, ed., "Sluzhba Sofii Premudrosti Bozhii iazhe v velikom Novegrade" ["The service of Sophia, God's Wisdom, as performed in Novgorod the Great"], in id., Sofiia Premudrost' Bozhiia, 21.

16. Cf. Viktor Byčkov, "Betrachtungen zur Genese der symbolisch-didaktischen Ikonen in Rußland vom Ende des 15. bis zum 16. Jahrhundert" in Karl Christian Felmy, ed., "Die Weisheit baute ihr Haus": Untersuchungen zu hymnischen und didaktischen Ikonen (München: Dt Kunstverl, 1999), 22.

17. Nikol'skii, ed., Sofiia Premudrost' Bozhiia, 20-21: “[...] Pesn' 7-ia hirmos: Iunoshi tri v Vavilone velenie muchitelevo na buistvo prelozhisha, i posrede ognia vverzheni, prokhlazhdaemi vopiakhu: blagoslovlen esi Gospodi Bozhe otets nashikh."

18. Marina Swoboda, "The Furnace Play and the Development of Liturgical Drama in Russia," Russian Review, 61, 2 (2002): 220-234.

19. Christoph Schmidt, Sozialkontrolle in Moskau: Justiz, Kriminalität und Leibeigenschaft, 1649-1785 (Stuttgart: Steiner, 1996), 13, 397-398, 405. 
20. Platonov, Skazanija, 300; SKKDR III/4, 278. See also above, note 13. On this rebellion, see N.N.Pokrovskii, Tomsk 1648-1649 gg. Voevodskaia vlast' i zemskie miry [Tomsk, 1648-1649. The voevoda's power and the local communities] (Novosibirsk: Nauka, 1989); however, he does not mention Shakhovskoi. The date of origin of his Sluzhba is not known.

21. Ihor Ševčenko, "A Neglected Byzantine Source of Muscovite Political Ideology," Harvard Slavic Studies, 2 (1954): 141-179, here 173-174.

22. Nikol'skij, "Sluzhba," 20. Derived from Maksim Grek's explanation of Wisdom: Bychkov "Betrachtungen," 22.

23. Theologically incorrect characterisation, which, however, fits the purpose.

24. Jacques Derrida, Force of Law, "The Mystical Foundation of Authority," Cardozo Law Review 11, 5-6 (1989-1990): 968, 971 (transl. by Mary Quaintance from Force de loi, P.: Galilée, 1994).

25. Hartmut Rüß, Herren und Diener: Die soziale und politische Mentalität des russischen Adels, 9.-17. Jahrhundert (Köln, et al.: Böhlau, 1994), esp.: p. 470, 438, 338, 328. Nancy S. Kollmann, Kinship and Politics: The Making of the Muscovite Political system, 1345-1547, (Stanford, CA: Stanford University Press, 1987). Sergei Bogatyrev, The Sovereign and His Counsellors: Ritualised Consultations in Muscovite Political Culture, 1350s-1570s (Helsinki: Suomalainen Tiedeakatemia, 2000).

26. Axel Honneth, "The Other of Justice: Jürgen Habermas and the Ethical Challenge of Postmodernism" in Stephen K. White, ed., The Cambridge Companion to Habermas, Ch. 6, (Cambridge: Cambridge University Press, 1995), 289-323 (repr. in James Penner, et al., eds., Introduction to Jurisprudence and Legal Theory: commentary and materials (London: Butterworth, 2002), 1115).

27. In Jewish context, the Torah; more generally, a code of law.

28. The tetragrammaton, in European languages often rendered Jehova or Jahve, from the original revelation (Gen 2:4) in Hebrew may be translated as "I am who I am" and thus cannot be named and fully comprehended or, in future tense "I will be who I will be" and thus will be with you, which became applicable both to Exodus and to intercession for the weak and deprived of their rights.

29. Martin Ebner, Jesus - ein Weisheitslehrer?: Synoptische Weisheitslogien im Traditionsprozess (Freiburg im Breisgau: Herder, 1998), 14-18; Lexikon für Theologie und Kirche (Freiburg im Breisgau: Herder, 2001), vol. 10, 1035, 1038, entry "Weisheit." Cf. Moshe IshHorowicz, "Righteousness (Tsedek) in the Bible and Its Rabbinic Interpretations," in Jože Krašovec, ed., The Interpretation of the Bible (Sheffield, 1979), 57-87. The main Byzantine sources on which Russian writers drew combined works of the Church fathers, the scriptures and Greek philosophy: Patrick Henry, "A Mirror for Justinian. The Ekthesis of Agapetus Diaconus," Greek, Roman and Byzantine Studies, 8, 4 (1967): 304.

30. Honneth, "The Other of Justice...," 1116.

31. Anne Barron, “(Legal) Reason and its 'Others': Recent Developments in Legal Theory," in Penner, ed., Introduction to Jurisprudence, 1055, 1073, 1075, 1081-1082.

32. This is the stance adopted by voevodas denounced for bribery and illegal trade, who claimed the suit endangered their capability to serve: Witzenrath, Cossacks and the Russian Empire, 127. 
33. P.B. Brown, "Neither Fish nor Fowl. Administrative Legality in Mid- and LateSeventeenth-Century Russia," JBGO, 50, 1 (2002):1-21. Costas Douzinas and Ronnie Warrington, Justice Miscarried: Ethics, Aesthetics and the Law (London: Harvester Wheatsheaf, 1994), Chapter 4, reprinted and edited in Penner, ed., Introduction to Jurisprudence, 1103.

34. Keenan, The Kurbskyi-Groznyi Apocrypha, 34.

35. PSRL 43, Moscow, 2004, 277, 1. 506.

36. On the reception by courtiers of representations of advice and advisors in the Kremlin Wisdom murals, see Daniel Rowland, "Two Cultures, One Throne Room. Secular Courtiers and Orthodox Culture in the Golden Hall of the Moscow Kremlin," in Valerie A. Kivelson, Robert H.Greene, eds., Orthodox Russia: belief and practice under the tsars (University Park, PA: Pennsylvania State University Press, 2003), 33-57.

37. Robert Crummey, "New Wine in Old Bottles? Ivan IV and Novgorod," Russian History, 14, 1-4 (1987): 75.

38. Priscilla Hunt, “Ivan IV's Personal Mythology of Kingship," Slavic Review, 52, 4 (1993): 788-792. Righteous terror was a form of justice customarily expected from rulers in some European countries: see Theo Broekmann, "Rigor iustitiae": Herrschaft, Recht und Terror im normannisch-staufischen Süden (1050-1250) (Darmstadt: Wissenschaftliche Buchgesellschaft, 2005).

39. Hunt, "Ivan IV's Personal Mythology...," 769, 809.

40. Andrei P. Pavlov and Maureen Perrie, Ivan the Terrible (London: Pearson/Longman, 2003), 32; Nancy S.Kollmann, Kinship and Politics; Cornelia Soldat, "The Limits of Muscovite Autocracy: The Relations Between the Grand Prince and the Boyars in the Light of Iosif Volotskii's Prosvetitel'," Cahiers du Monde russe, 46, 1-2 (2005): 273-276.

41. Derrida, Force of Law, 971. My parenthesis quotes a close by sentence explaining the phrase.

42. Hunt, "Ivan IV's Personal Mythology...," 769-809.

43. Roger Chartier, "Introduction," in idem, Cultural History: Between Practices and Representations (Cambridge: Polity, 1993 [1988]), 13-14.

44. "Pritchi Solomoni [Proverbs of Salomon], 8, 15, in Biblija: Sirech knigi vetkhago i novago zaveta po iazyku slovensku [The Bible. That is, the books of old and new testaments in slavonic language], Kommissiia po [...] izdaniiu pamiatnikov pis'mennosti [...] Fototipicheskoe [...]s teksta 1581 [Ostrikh], 1988: "With my help the tsars rule, and the strong people write the laws." (Proverbs, 8, 15).

45. Nikol'skij, "Sluzhba," 18: "With her help the kings ["tsars"] rule, the strong hold the land and wise people write the laws." (Proverbs, 8, 15).

46. On suckling, spiritual nourishment and the negative role of wine in the Gnostic writings, see Michael Lattke, ed., Die Oden Salomos in ihrer Bedeutung für Neues Testament und Gnosis, (Freiburg, Switzerland: Universitätsverlag, 1986), 354; Majella M. Franzmann, "A Study of the Odes of Salomon with Reference to the French Scholarship 1909-1980," ibid., 392-396.

47. The underlying image of the path is introduced earlier: Nikolskii, "Sluzhba," 17: "Dar blag daet nam Sofiia Premudrost' Bozhiia i putem pravym teshi nastavliaet nas, ashche techem putem tem, ne zapnemsia i sokhraniaem sebe v zhivot vechnyi. 
48. Cf. Prov 8:1-20. Transl. acc. to Nikol'skii, "Sluzhba," 21: "Ruka izbrannykh uderzhit premudrost' Bozhiiu, luchshe bo est' srebra i zlata i na versekh sten propoveduetsia i vo vratekh sil'nykh prisedit' i derzhaiushchi glagolet' raduitesia so mnoiu vzyskaiushchii mene. Slavu premudrostiiu Bozhieiu nasledova, ta bo est' dolgota zhivota i leta zhizni daruet i mir prilagaet i vsia blagaia ispravliaet i put' zhizni sokhraniaet nam. Slava: Tvoria pravdu nasledit Premudrost' Bozhiiu Sofiiu imenovannuiu, iako blaga sosca eia pache vina i vonia mira eia pache vsekh aromat, techem da sud i pravdu daruet nam;" I.I. Sreznevskii, Materialy dlia slovaria drevne-russkago jazyka [Materials for a dictionary of ancient Russian] (SPb., 1902), vol. II, col. 1357 (entry "pravda"): Law code - "I siiu pravdu polozhi prezh nimi." SlRIa, vol. 18, p. 97 ("pravda," § 5), p. 98 ("pravda," \$ 8) - "Vziati pravdu" - to win a lawsuit; "V pravdu" - according to the rules, the laws; lawful. Spasskij translates: "donne le jugement et la justice" (Théodore Spasskij, "L'office liturgique slave de la Sagesse de Dieu," Irénikon XXX, (1957): 180).

49. The narrow path to justice and Wisdom, see below on the murals in the Golden Palace.

50. Derrida, Force of Law, 966. Cf. Anselm Haverkamp, Gewalt und Gerechtigkeit: DerridaBenjamin (Frankfurt am Main: Suhrkamp, 1994), 37. Habermas and Dworkin both offer ways of dealing with this. However, their approaches require fairly ideal, "modern" conditions of public accountability and exchange between institutionalised spheres of governance and informal public spheres: Jürgen Habermas, Between Facts and Norms: Contributions to a Discourse Theory of Law and Democracy (transl. by W. Rehg) (Cambridge: Polity, 1996), 299; Barron, “(Legal) Reason...," in Penner, ed., Introduction to Jurisprudence, 1084.

51. Isolde Thyrêt, Between God and Tsar: religious symbolism and the royal women of Muscovite Russia (DeKalb, IL: Northern Illinois University Press, 2001), 152-154.

52. Derrida, Force of Law, 964.

53. Thyrêt, Between God and Tsar, 154-156.

54. Kollmann, Kinship and Politics

55. N.S. Kollmann, "The Quality of Mercy in Early Modern Legal Practice," Kritika, 7, 1 (2006): 5-22; Horace W. Dewey, "Old Muscovite Concepts of Injured Honour (Beschest'ie)," Slavic Review, 27 (1968): 594-603.

56. Derrida, Force of Law, 968-969. Lexikon für Theologie, vol. 10, entry "Weisheit," 1035. On the "small" eschatology, see n. 52 .

57. Brown, "Neither Fish nor Fowl..."

58. N.S. Kollmann, "Judicial Autonomy in the Criminal Law: Beloozero and Arzamas," FOG, 63 (2004): 66-68.

59. Hans-Joachim Torke, Die Staatsbedingte Gesellschaft: Zar und Zemlia in der altrussischen Herrschaftsverfassung 1613-1689 (Leiden: Brill, 1974), 90-91; cf. the oath sworn by undersecretaries: Natal'ia Fedorovna Demidova, Sluzhilaia biurokratiia $v$ Rossii XvII v. i ee rol ' $v$ formirovanie absoliutizma [Imperial bureaucracy in XVII th Russia and its role in the formation of absolutism] (M., 1987), 149.

60. On the ways in which it dealt with "evil" tsars, see Daniel B. Rowland, "Did Muscovite Ideology Place Limits on the Power of the Tsar (1540s-1660s)," Russian Review, 49 (1990): 125-155. 
61. "According to the law" - "v pravde": po zakonu ("torgovye liudi, prinuzhdeny... vdvoe poshliny platiat, chevo v pravde ne dolzhny" or translated as "justice" or "rectitude" ("pravda", \& 8, see footnote 48 above).

62. Cf. N.N. Pokrovskii, Tomsk 1648-1649 gg., 326; further discussion of this letter, cf. Witzenrath, Cossacks and the Russian Empire, 116-117.

63. Vadim Aleksandrovich Aleksandrov and N.N. Pokrovskii, Vlast' $i$ obshchestvo: Sibir' v XVII v. [Power and society] (Novosibirsk: "Nauka" sibirskoe otd-nie, 1991), 288.

64. Witzenrath, Cossacks and the Russian Empire. On variations of local administrative cultures in another empire, see Birgit Emich, et al., "Stand und Perspektiven der Patronageforschung," Zeitschrift für Historische Forschung 32, 2 (2005): 247-51.

65. Aleksandrov, Vlast' i obshchestvo, passim.

66. PSRL vol. 36, 1, 380, 1. 86 and 124, 1.18. Daniel Rowland, "Did Russian Literary Ideology Place any Limits on the Power of the Tsar (1540s-1660s)," Russian Review 49, 2 (1990): 125-155. Witzenrath, Cossacks and the Russian Empire, 52-53.

67. On cossack literacy: C. Witzenrath, "Literacy and Orality in the Eurasian Frontier: Imperial Culture and Space in Russia," The Slavonic and East European Review 87, 1 (2009): 53-77.

68. Pokrovskii, Tomsk 1648-1649 gg., 157. Further examples of advice in Witzenrath, Cossacks and the Russian Empire, 49-51, and Index; Dmitrii Ia. Rezun, Russkie $v$ Srednem Prichulyme XVII-XVIII vv. (Novosibirsk, 1984), 49.

69. Pokrovskii, Tobol'skii arkhiereiskii dom, kn. “Б”, p. 93, ff. $44 \mathrm{v}^{\circ}-45 \mathrm{v}^{\circ}$.

70. Maikl Flajer (Michael Flier), "K semioticheskomu analizu zolotoi palaty Moskovskogo kremlia" ["A contribution to the semiotic analysis of the Golden Chamber in the Moscow Kremlin"], in Andrei L. Balatov, et al., ed., Drevnerusskoe iskusstvo pozdnego srednevekov'ia: XVI vek [Russian art of the late Middle Ages: the XVI ${ }^{\text {th }}$ century] (SPb.: Dmitrij Bulanin, 2003), 178-187.

71. According to Aquinas, human law is related to the Last Judgement "because man is destined to an end of blessedness, and this exceeds what is proportionate to natural human faculties [...] it was necessary that he should be directed to this end not merely by [...] human law, but also by a divinely given law." Both of which ultimately derive from Divine Wisdom: Penner, Introduction to Jurisprudence, 54.

72. The candle-stick is mentioned in descriptions, but hitherto has not been traced: cf. Frank Kämpfer "Rußland an der Schwelle zur Neuzeit," JBGO (1975): 510. Rudolf Schneider, ed., Die moralisch-belehrenden Artikel im altrussischen Sammelband Merilo pravednoe (Freiburg im Br.: Weiher, 1986), XIX. Kuritsyn excluded parts directed against Jews. Any study of the Merilo's reception in Muscovy would have to engage the plentiful Rudders. Cf. also Iakov Solomonovich Lur'e, "Kuricyn Ivan-Volk," SKKDR II/1, 503-504.

73. Rowland, "Two Cultures, One Throne Room..."

74. Schneider, Die moralisch-belehrenden Artikel, 23-26, 37; Kämpfer, "Rußland an der Schwelle...," 510. Semen Ul'ianovich Remezov, Khorograficheskaia kniga, Houghton Library, Harvard University, MS. Russ 72 (6), f. 8. On the relation of the scales to the "small" eschatology, the belief in an individual judgement in the beyond which good deeds could influence, which developed in Russia in the fifteenth century, see Aleksei Ivanovich Alekseev, Pod znakom konca vremen: Ocherki russkoi religioznosti kontsa XIV- 
nachala XVI $v v$. [Under the sign of the end of time] (SPb.: Aleteiia, 2002), 87-88 (review in Cahiers du Monde russe, 44, 4 (2003): 691-693 by Petre Guran).

75. Pokrovskii, Tomsk 1648-1649 gg., 46. Deti boiarskie ranked just above rank-and-file cossacks, but their allegiances were volatile due to the power resources wielded by the cossack group.

76. Nikolai Kostomarov, ed., "Povest' grada Erusalima" ["The Tale of the town of Jerusalem"], Pamiatniki starinnoi russkoi literatury [Monuments of ancient Russian literature], vol. 2: Skazanija, legendy, povesti, skazki i pritchi [Narratives, legends, stories, tales and parables], SPb., 1860, II, 307. Markus Osterrieder, "Das Land der Heiligen Sophia," Wiener Slawistischer Almanach 50 (2002): 29, 35. It could also mean the tsar: SlRJa, vol. 26, 129-130, entry "solnce", § 3: "Milosti prosim u tebia [caria], solnca khristiianskago, osveti nas i vsiu Velikuiu Rusiiu, dazhd' nam pravednyi sud" (taken from: "Chelobitnaia Lazaria," 1668, in Nikolai Ivanovich Subbotin, ed., Materialy dlia istorii raskola za pervoe vremia ego sushchestvovaniia [Materials for the history of Raskol in the first period of its existence], vol. 4, 229].

77. Valerie Kivelson, Cartographies of Tsardom: the land and its meanings in seventeenthcentury Russia (Ithaca, NY: Cornell University Press, 2006), plate 18, 20, 23, fig. 5.5, p. 209. S.U. Remezov, Kratkaia sibirskaia letopis' (Kungurskaia) [Short Annals of Siberia (from Kungur)] (Irkutsk, 2003 [1880]), 18, 37, 155. The later (1680's) Tobolsk icon of Sophia was painted as the woman from the Apocalypse (Revelation, 12,1,14), standing on a crescent moon, symbol of earthly wisdom, clothed in sun rays, a theme spread by the Jesuits: G.V. Florovskii, "O pochitanii Sofii, Premudrosti Bozhiei, v Vizantii i na Rusi," in Trudy $V$-go s" ezda russkikh akademicheskikh organizacii za granitsei v Sofii 14-25 sentiabria 1930 goda [V Congress of Russian academic bodies outside Russia] I (1932), 485-500, 498. Cf. the sun in the Golden Hall: Rowland, "Two Cultures, One Throne Room," figs. 3-5. Yuri Slezkine, Arctic Mirrors: Russia and the small people of the North (Ithaca: Cornell University Press, 1994), Chapter 1.

78. Kivelson, Cartographies of Tsardom, 212-213.

79. In 1648-1649, natives supporting the Tomsk rebels set up a road block to control the flow of news: Pokrovskii, Tomsk 1648-1649 gg., 234.

80. Remezov, Kratkaia sibirskaia letopis', 168. Cf. Kivelson, Cartographies of Tsardom, 196. On Remezov's Muscovite and frontier cultural outlook: ibid., 137.

81. Ibid., passim.

82. Witzenrath, "Remote Power in the Orthodox Church..."

83. Distinguished by autonomous rule-making capacities for internal use, professionalization of staff, but limited by the lack of full public control and the venality of officials. Cf. note 33.

84. Valerie Kivelson provides evidence to their important role as legal subjects in the seventeenth century: Cartographies of Tsardom, 51, 55, 84.

85. Isolde Thyrêt, Between God and Tsar. 


\section{ABSTRACTS}

Abstract

The foundation of the Siberian archbishopric forms the backdrop of a discussion of S.U. Shakhovskoi's Divine Wisdom service, employing postmodern legal philosophy to discuss how he addresses structural uncertainty in court, the aporia of justice. He expounds the limitations of the ruler as finite human being facing the infinite and immediate demands of justice: its procedural aspect appears as an image of the path; its urgent aspect is addressed by the idea that Wisdom aids the ruler, but remains a mystery. Shakhovskoi's views contrast with Ivan IV's, who believed in his direct access as tsar to Divine Wisdom, repudiating his boyars' 'wise' advice in favour of populism and violent purification. Social practices gave meaning to representations of Wisdom in multiple ways. In Siberia, cossacks deposed voevodas who refused to listen and submit to common aims. The first archbishop institutionalised these interpretations, thereby popularising Wisdom. Using the image of the path, representations of Wisdom referred to the spatial dimension of justice in an expanding empire, postponing the tsar's final discretion.

Résumé

Avec, comme toile de fond, la création de l'archevêché de Sibérie, l'article examine l'office de la Divine Sagesse, composé par Semen Ivanovič Šahovskoj, à la lumière de la philosophie postmoderne du droit. Celle-ci aide à comprendre comment Šahovskoj traite l'aporie de la justice, à savoir l'incertitude structurelle propre à tout tribunal humain. Il expose les limitations du monarque, qui sont celles d'un être humain fini, face aux exigences infinies et immédiates de la justice. La procédure judiciaire est évoquée à travers l'image du chemin. Pour répondre à l'urgence de juger, Šahovskoj espère en la Sagesse divine, qui viendra au secours du monarque, mais reste cependant un mystère. La façon de voir de Šahovskoj est aux antipodes de celle d'Ivan IV, qui croyait qu'en sa qualité de tsar il avait directement accès à la Sagesse divine, et, faisant fi des «sages " avis de ses conseillers, préférait une politique populiste et la purification par la violence. La pratique sociale donnait sens aux représentations de la Sagesse, et cela de multiples façons. En Sibérie, les cosaques déposaient les gouverneurs qui refusaient de prêter l'oreille et de se soumettre aux impératifs du bien commun. Le premier archevêque sibérien institutionnalisa ces interprétations, ce qui contribua à populariser le culte de la Sagesse. La métaphore du chemin permettait de donner aux représentations de la Sagesse, et, du même coup, à la justice, une dimension spatiale: elle s'étendait au même rythme que l'empire, retardant d'autant le bon plaisir du tsar.

\section{AUTHOR}

\section{CHRISTOPH WITZENRATH}

University of Aberdeen, Department of History 